\title{
"Islamic Education in Southeast Asia: A Study of the Integration of Knowledge in Brunei Darussalam"
}

\author{
Ahmad F. Yousif ${ }^{1}$, Norarfan Hj. Zainal ${ }^{2}$ \\ (ahmad.yousif@unissa.edu.bn ${ }^{1}$, norarfan.zainal@unissa.edu.bn $^{2}$ ) \\ (Associate Professor, Sultan Sharif Ali Islamic University (UNISSA), Brunei Darussalam ${ }^{1}$, Rector, \\ Sultan Sharif Ali Islamic University (UNISSA), Brunei Darussalam²)

\begin{abstract}
In Southeast Asia (SEA) as well as other parts of the Muslim world, academic institutions of higher learning often ignore the importance of integration of knowledge as an instrument for determining solutions to contemporary challenges, including social change in digital era. This is especially evident in the field of Islamic Studies. The majority of Islamic institutions in SEA develop their academic programs utilizing traditional approaches and techniques. Although such approaches do have some merits, they have a number of disadvantages. This paper will introduce a brief history of the concept "integration of knowledge" in Islamic tradition, and its application within higher educational institutions in SEA, exploring the model at the Sultan Sharif Ali Islamic University (UNISSA), Brunei Darussalam. It is hoped that this academic exploration will lead towards the development of a new learning approach among Islamic educational institutions in and outside

SEA.
\end{abstract}

Keywords: Religion, Education, Integration of Knowledge, Tradition, Modern, Southeast Asia, Brunei Darussalam

\section{Introduction}

The majority of Islamic institutions of higher learning in Southeast Asia (SEA) offer academic programs in Islamic disciplines using traditional approaches and techniques. Although such approaches do have some merits, they have a number of disadvantages. Consequently, many scholars and students in the Islamic institutions often face difficulties and challenges when learning and/or conducting research due to the use of methodologies which lack innovativeness, efficiency, critical thinking and over-all effectiveness. In an effort to reduce some of the deficiencies of the traditional approach to learning, some scholars prefer to completely reject such methods in favour of western educational approach. $\left[{ }^{1}\right]$

This orientation towards western educational system developed largely due to two primary factors. First of all, some members of the Muslim intellectual community regard such system as being more sophisticated and appropriate for their societies. Secondly, there is a lack of up-to-date learning centres based on the Islamic worldview in our modern ummah. Although in some disciplines western educational approach may be acceptable for some, in the Islamic disciplines or social sciences, the need for a fresh approach is critical. Prior to examining the merits and demerits of traditional educational system particularly in the Islamic institutions, it is essential to have a proper understanding of the Islamic concept of knowledge.

This paper will introduce a brief history of the concept "integration of knowledge" in

${ }^{1}$ A "western educational approach" in this context refers to and for the sake of this paper, as the "secular," "modern" educational system. 
Islamic tradition and its application within higher educational institutions in SEA, exploring the model at the Sultan Sharif Ali Islamic University (UNISSA), Brunei Darussalam. The method utilized in this study is based on qualitative analysis, in addition to theories and writings of contemporary Muslim intellectuals. It is hoped that this academic exploration will lead towards the development of a new learning approach among Islamic educational institutions in and outside SEA.

\section{Islamic Concept of Knowledge}

The majority of Muslim intellectuals regard Islamic knowledge as a revealed and divine knowledge to all mankind. According to Ismail R. al-Faruqi, the concept of knowledge, is based on the recognition that Allah is al Haqq (the Truth) and that He is One. He is also the all-Omnipotent (all Knowing), Whose knowledge is both absolute and universal. $\left.{ }^{2}\right]$ It is Allah who "taught man the use of the pen. He taught him what he did not know" [Qur'an 96:45]. The Qur'an also tells us that it was "Allah who taught Adam the names (essences) of all things" [Qur'an 2:31]. Ismail R. al-Faruqi Syed Muhammad Naquib al-Attas classifies Islamic knowledge into two categories. The first is the knowledge given by Allah to man via revelation. Although this form of knowledge is limited, it is nevertheless regarded as the highest form of knowledge and it is obligatory on every Muslim to learn, understand and implement. All knowledge in this category is given by Allah to man for his benefit. The second form of knowledge is that acquired by man through rational inquiry based on experience and observation. $\left[{ }^{3}\right]$ Al-Attas argues that not all knowledge in this category is necessarily good for man. $\left[{ }^{4}\right]$

Contrary to secular philosophy which rejects all forms of knowledge which can not be empirically tested and confirmed, the majority of Muslim scholars recognize that there are limitations to human knowledge. According to Ismail R. al-Faruqi Syed Muhammad Naquib al-Attas Zaghlul R. al-Najjar, an Egyptian scientist,

... many higher truths cannot be reached through human thinking alone or via the limited methods of scientific research. We have no means for knowing such higher truths except through Divine revelation...[which] is the highest level of human knowledge. $\left[{ }^{5}\right]$

The importance of seeking and acquiring both divine and worldly knowledge in Islam was stressed from the very first revelation, "Read in the name of Your Lord, who created, created man from a clot" (Qur'an 96:1-2). Numerous Prophetic traditional Hadiths further attest to this fact, for example: "... learning and the pursuit of knowledge is obligatory on every Muslim..." [ $\left.{ }^{6}\right]$ and,

\footnotetext{
${ }^{2}$ Ismail R. al-Faruqi. Al-Tawhid: Its Implications for Thought and Life. Virginia, USA: International Institute of Islamic Thought, 1992, p. 42; see also Ismail R. al-Faruqi and Lois Lamya al-Faruqi. "The Essence of Islamic Civilization," in The Cultural Atlas of Islam. New York, USA: Macmillan Publishing Company, 1986, pp. 73-90.

${ }^{3}$ Syed Muhammad Naquib al-Attas. Islam and Secularism. Kuala Lumpur, Malaysia: ABIM, 1978, p. 74.

${ }^{4}$ Syed Muhammad Naquib al-Attas. Islam and Secularism, p. 79.

${ }^{5}$ Zaghlul R. al-Najjar. "Islamizing the Teaching of Science: A Model in Challenge and Response," in Islam: Source and Purpose of Knowledge. Virginia, USA: International Institute of Islamic Thought, 1983, p. 142. ${ }^{5}$ Ismail R. al-Faruqi. Al-Tawhid: Its Implications for Thought and Life. Virginia, USA: International Institute of Islamic Thought, 1992, p. 42.

${ }^{6}$ Compiled by Ibn Maja, al-Sunan.
} 
"If anyone pursue a path in search of knowledge, Allah will thereby make easy for him a path to paradise, and the angels spread their wings from good pleasure with one who seeks knowledge, and all the inhabitants of the heavens and the earth, even fish in the depths of water, ask forgiveness for him.". ["]

Traditional Arabic proverbs have also emphasized the importance of seeking knowledge. For instance, an individual is encouraged to "seek knowledge from the cradle to the grave," even if this means "seeking knowledge in China." Accordingly, many scholars perceive the search for knowledge as an act of ibadah (worship), as long as the seeker is sincere in his/her pursuit and pursues such knowledge with the intention of pleasing Allah.

As a methodological approach in Islamic tradition, knowledge consists of three basic principles. First, anything which does not correspond with reality must be rejected. Secondly, ultimate contradictions must be denied, and thirdly Muslims must be open to new and/or contrary evidence. $\left[{ }^{8}\right]$ The verification of one's conclusions or knowledge with these principles in order to confirm their validity is best illustrated by the Qur'anic story of the Prophet Ibrahim's search for the Truth, via his own limited senses and reason. In an attempt to know his Creator, the Prophet was forced to reject a number of hypothesis which did not correspond with reality. Ultimately, however, he came to the conclusion that neither the stars, the moon, nor the sun could possibly be his Creator, since themselves must have had a Creator [Qur'an 6:76-79].

Some of the greatest merits of the traditional approach were the sincerity, piety, enthusiasm, attachment, commitment, dedication, devotion and freedom of the early Muslim educationists. In contrast to today, when the majority of scholars is conducted their work for economic gains or professional benefits, many of the early scholars were not motivated by monetary interests, but looked for their rewards in the Hereafter. Islamic research, experimentation and empirical investigation were considered acts of ibadah (worship) and accordingly were pursued with much vigour and enthusiasm. The God-consciousness of the traditional scholars was reflected in their writings and research, which they would commence with bismillah (in the name of Allah) and end with Allah-u-Alam (Allah Knows the best), seek His blessings and conclude by dedicating their results to Him. $\left[{ }^{9}\right]$

In fact the holistic nature of the traditional Islamic educational system made no distinction between revealed knowledge and empirically derived knowledge. Islamic knowledge was perceived as a comprehensive whole, with empirically derived knowledge subject to the verification of revealed knowledge. Being fully cognizant of their tremendous responsibilities as Khalifah (to please Allah and serve mankind), the early scholars took great pains to ensure their work was as accurate as possible given the instruments available during their day. Their strong iman (faith) and taqwa (God-fearing) prevented them from accepting any conclusions which contravened revealed knowledge. All contradictions were scrupulously reviewed with the sincere intention of arriving at the truth.

Another merit of the traditional approach was that the early scholars had greater familiarity with classical Arabic language than contemporary scholars (including those of Arabic-speaking origin). This linguistic advantage facilitated their understanding and analysis of the original texts and prevented them from arriving at wrongly deduced interpretations and conclusions. Furthermore, traditional scholars used classical Arabic language in their works

\footnotetext{
${ }^{7}$ Compiled by Ahmad Ibn Hanbal, al-Musnad.

${ }^{8}$ Ismail R. al-Faruqi. Al-Tawhid: Its Implications for Thought and Life, p. 43.

${ }^{9}$ Imad al Din Khalil. "Islamization of Knowledge: A Methodology." Occasional Paper No. 2 Virginia, USA: International Institute of Islamic Thought, 1991, p. 8.
} 
(including those ethnically non-Arabs), thereby perpetuating the link between understanding the original sources and their own research.

While traditional Islamic educationists used the latest instruments and techniques of their day to conduct, verify and validate their research, there is little question that such efforts were very time consuming due to the limited means of communication and transportation. Moreover, as Islam spread from its origins in the Arabian peninsula to other parts of the world including SEA, Muslim scholars and researchers began to be influenced by the ideologies, lifestyles and cultures of foreign lands. Ideas contrary to Islamic tenets often influenced the nature of knowledge undertaken and the results achieved, much to the chagrin of the traditional ulama.

The traditional religions practiced in a particular geographical region, also affected the development of Islamic thought, research techniques and teaching methodologies utilized. This is especially true in the Southeast Asian context where the influence of native traditions, Hinduism, Buddhism, various Chinese religions and Christianity are particularly visible in the social values and norms of the society. The fact that Islam spread to the region via Sufi or$\operatorname{ders}\left[{ }^{10}\right]$ has also coloured the perception and development of Islam in the area, which in turn has influenced the nature of Islamic knowledge undertaken and the type of teaching methodologies employed.

Although the Arabic language is used in the majority of contemporary madrassahs in Southeast Asia, enabling many scholars to master the Arabic language and understand the concept of religion well, Ismail bin Haji Ibrahim, former Director of the Institute of Islamic Understanding Malaysia (IKIM), argues that the biggest problem facing researchers in Southeast Asia is their inability to "apply what they learned [in the madrassah] to current issues and new problems". Due to the fact that the madrassahs tend to rely strictly on the "memorization of classical texts," many students come to perceive Islamic studies as being little more than "prayers, fasting, wudhu [ablution] etc." and "nothing to do with their values and culture." $\left[{ }^{11}\right]$ Subsequently, when these scholars enter the "real world," they are unable to fully utilize the information they received to resolve the issues and challenges facing their societies. Commenting on Malaysian context, Ismail R. al-Faruqi Syed Muhammad Naquib al-Attas Zaghlul R. al-Najjar, M. Kamal Hassan sums up this issue very aptly,

The culture which nurtures a slavish mentality begins in the home where parents assert their overbearing authority over the children and discourage their freedom of expression. The home or social environment instills fear and awe before human authority and discourages critical thinking...It pays to be an "obedient servant" of the powerful bosses. [ $\left.{ }^{12}\right]$

In other words, the conservative view held by the madrassahs of what was considered "Islamic knowledge", made them ineffective in producing scholars who would be capable of dealing with their society's challenges in an Islamic manner. This tendency to separate knowledge into "religious" and "non-religious" further limited the scholars in undertaking research which would effectively address their socio-religious challenges.

\footnotetext{
${ }^{10}$ Martin van Bruinessen. "The Origin and Development of Sufi Order (Tarekat) in South East Asia." Studia Islamika, (Indonesian Journal for Islamic Studies) Vol. 1, No. 1, (1994), p. 4.

${ }^{11}$ Excerpt from an interview with Dato Ismail Bin Haji Ibrahim, Institute of Islamic Understanding Malaysia (IKIM), Kuala Lumpur, Malaysia, October 15, 1995.

${ }^{12}$ M. Kamal Hassan. "Some Socio-Cultural Phenomena Which Hinder the Overall Progress of the Muslim Ummah: General Observations Related to the Malay Community in Malaysia Facing the Challenges of the 21st Century." Paper presented at the International Conference on "Comprehensive Development of Muslim Countries from an Islamic Perspective" Subang Jaya, Selangor, Malaysia, 1994, p. 39.
} 
Other difficulty facing the traditional Muslim educationists and their selection of a particular teaching methodology are limited access to original Islamic sources (especially for non-Arabic speaking teachers), the tendency to confine oneself to a particular school of thought, financial disabilities, shortage of adequate facilities, lack of qualified human resources, unprofessional management skills as well as a general overall lack of confidence.

Having reviewed the merits and shortcomings of the traditional Islamic educational system, our challenge is how to develop a methodology which will be able to combine the "best of both worlds." What are some of the recommendations which can be made to contemporary Islamic institutions in Southeast Asia, and the rest of the Muslim world for that matter. The following part of this paper will explore the model of religious education in Brunei Darussalam, and examine the learning system at Sultan Sharif Ali Islamic University (UNISSA). In order to understand religious education in Brunei Darussalam, a brief history of Islam and its influences on the society will be introduced.

\section{History of Islam in Brunei Darussalam}

The Sultanate of Brunei Darussalam, located on the North-West coast of the Island of Borneo, in Southeast Asia, has a small population compared to other neighbouring countries. The Department of Economic Planning and Statistics in Brunei Darussalam stated that the national population in 2019 is estimated at 459,500 persons. [ ${ }^{13}$ ] Approximately two-thirds $(66 \%)$ of Brunei's population consist of ethnic Malays, the absolute majority of which are Sunni Muslims, who follow the Shafi'i school of Islamic thought (Madhhab al-Shafi'i). The ethnic Malay community in the country includes Melayu Brunei, Tutong, Belait, Dusun, Kedayan, Murut and Bisaya, who speak Malay langua ge (Bahasa Melayu) and use English as a second language. The Chinese community comprised of ten percent $(10 \%)$ of the ethnic distribution, while the remaining "Others" represents twenty-four percent $(24 \%)$ of Brunei's population. $\left[{ }^{14}\right]$ Members of the Chinese community speak different Chinese dialects including Hokkien, Mandarin, Hakka and Cantonese.

In terms of religious distributions, Brunei Darussalam is officially a Muslim nation, as stated in the country's Constitution of 1984. The Sultan and Yang Di-Pertuan (a royal title) has been the head of the Islamic faith since the late thirteen century. Although Islam is the official religion of the country, religious minorities have the right to observe their religious values and traditions. In this regard, Article 3(1) of the Constitution of Brunei Darussalam (1984), asserts that, “... all other religions may be practiced in peace and harmony by the persons professing them in any part of Brunei Darussalam." $\left[{ }^{15}\right]$ As far as the religious statistics of Brunei is concerned, the 2018 census indicated that, out of $\square 442,000$ population, $\square \square \square \square \square \square \square \square$ approximately $67 \%$ identified themselves as Muslims, 13\% Buddhists, 10\% Christians, and the remaining 10\% "Others", which includes other religious groups such as Hindus, Sikhs, and non-affiliates. [ $\left.{ }^{16}\right]$

\footnotetext{
${ }^{13}$ Department of Economic Planing and Statistics, Brunei Darussalam. "Population 2019". Cited from http://www.deps.gov.bn/SitePages/Population.aspx, on July 19, 2020.

${ }^{14}$ Cited from hhttp:/www.deps.gov.bin/SitePages/Population.aspis, on June 24, 2020.

15 The Constitution of Brunei Darussalam (Revised Edition 1984). Cited from hatpps:/www.worldstatesmem.org/Brunei1984.PDF, 16, on July 20, 2020.

${ }_{16}$ Brunei Darussalam Statistical Yearbook 2018. Brunei Darussalam: Department of Statistics, 200.
} 
There are a number of theories regarding the origins of Islam in Brunei Darussalam. One theory is that Islam came to Brunei from China, another traces its route to Arab traders who came to Southeast Asia during the fourteen and fifteen centuries, from Hadramawt in Yemen and possibly through Gujurat, India. Pehin Jamil, former head of the History Center in Brunei, asserts, that the majority of early Muslim intellectuals who came to Java, Sumatra, Borneo and Celebes, were descendants of the Prophet Muhammad and were of Arabic origin. $\left[{ }^{17}\right]$ By the mid-16 ${ }^{\text {th }}$ century, Brunei Darussalam became a dominant regional power. With the coming of the Spanish and the British to the region in the latter half of the $16^{\text {th }}$ century however, Brunei's political power gradually eroded, until it became a British Protectorate in 1888 .

Both in the past and in the present, Islamic values, traditions and ethics have been incorporated and manifested within Brunei's culture, society and politics. Proof of the continuous link between religion and state, past and present, is the continuation of the MIB (Melayu Islam Beraja or Malay Islamic Monarchy) philosophy which has been in existence, since Brunei first declared itself a Malay Muslim Sultanate six centuries ago. MIB is the cornerstone of the socio-political ideology of modern-day Brunei Darussalam, which stresses the importance of maintaining monarchy political system, Malay race, language, culture and Islam as a religion of the nation.

Religious institutions for both Muslims and non-Muslims are spreading out around the country. According to the Mosque Affairs Department, there are one hundred and seven (107) Mosques and Suraus (prayer hall) and eleven (11) non-Muslim worship places in Brunei as of 2018, $\left[{ }^{18}\right]$ including two major state mosques, Masjid Omar Ali Saifuddien and Jame' Asr Hassanal Bolkiah, both of which are considered major tourist attractions for visitors to Brunei.

The majority of Islamic organizations or departments in Brunei are government or semi-government established and maintained. The Ministry of Religious Affairs, established in 1986, is comprised of six (6) different departments, namely, Administration, Islamic Studies, Hajj (pilgrimage), Mosque Affairs, Shari'ah Affairs (Islamic Law), and Islamic Religious Council. In addition, educational institutions such as the Islamic Da'wah Center (propagation centre), Seri Begawan Religious Teachers University College and Sultan Haji Hassanal Bolkiah al-Qur'an Tahfiz Institute (hittp://itgshlab.blogspot.com) are included. The Ministry has an informative website (http://www.kheu.gov.bn/Theme/Home.aspx) which can be accessed in Malay language. $\left[{ }^{19}\right]$

The Islamic Da'wah Center established in January 1985, is responsible for the dissemination and expansion of Islamic teachings among both Muslims and non-Muslims in Brunei Darussalam. It also undertakes research and studies on Islamic related subjects, publishes Islamic material such as books, pamphlets, periodicals, and networks with other Muslim countries, by exchanging information and organizing intellectual conferences, seminars and meetings on various contemporary Islamic issues. The Center's Publication Control and Cen-

\footnotetext{
${ }^{17}$ Ahmad Yousif, "Religious Life and Institutions in Brunei," ISIM Newsletter, International Institute for the Study of Islam in the Modern World, Leiden University, The Netherlands, No.5, 16 (July 2000). Accessed from https://openaccess.leidenuniv.nl/bitstream/handle/1887/17397/ISIM 5 Religious Life and Institutions in Brunei.pdf?sequence $=1$ on July 27, 2020; see also Chiara Formichi (2016), "Islamic Studies or Asian Studies? Islam in Southeast Asia." The Muslim World, Vol. 106, p. 716.

${ }^{18}$ Brunei Darussalam Statistical Yearbook 2018. Brunei Darussalam: Department of Statistics, 201.

${ }^{19} \mathrm{Cited}$ from hhttp://www.kheu.gov.bm/SitePages/Isul-Isu\%20K/Kas\%20Mengenai\%20Covid19.aspx, on June 6, 2020.
} 
sor Unit monitors books, periodicals, journals, newspapers and other materials, which contradict Islamic belief and teachings.

Moreover, Sufi groups or tariqahs (mystical orders), particularly al-Ahmadiyyah and al-Naqshabandiyyah have also established themselves in the country. Some of these tariqahs trace their roots directly to the Middle East, while others entered Brunei via neighbouring countries such as Indonesia and Malaysia. Many of these groups engage in a weekly Dhikir, a socio-religious ceremony in which religious poems are read and chanted.

\section{Religious Education in Brunei Darussalam}

The $20^{\text {th }}$ century witnessed the growth and development of Islamic religious education in Brunei Darussalam. In 1956, seven full-time Islamic schools were officially opened. Since then, the number of religious schools has increased to 160 schools, ninety-nine of them located in Brunei-Muara district, twenty in Belait, twenty-nine in Tutong and twelve in Timbering. $\left[{ }^{20}\right]$ Religious (Guam) classes are also taught in the public schools. According to Haji Abdul Rahman Bin Haji Nawi, the former Director of curriculum development at the Ministry of Education, "Ugama (Islamic) lessons are offered as a subject called 'Islamic Religious Knowledge' (IRK). Students need to take this subject two hours each week at the secondary and the primary school levels, divided into four periods a week, each of which lasted thirty minutes." $\left[{ }^{21}\right]$

Islamic education is also promoted under schools and colleges affiliated with the Ministry of Religious Affairs, where traditional Islamic subjects are taught in both Malay and Arabic languages. Some of the more reputable religious institutes in the country are the Sultan Haji Hassanal Bolkiah Tahfiz al-Qur'an Institute, the Brunei College of Islamic Studies (Ma'had) and the Seri Begawan Religious Teachers University College (KUPU-SB).

The Institute Tahfiz al-Qur'an Sultan Haji Hassanal Bolkiah ${ }^{22}$ located in the center of the Bruneian capital, operates under the Ministry of Education, and presently accommodates forty-two (42) boy and forty-one (41) girl students. ${ }^{23}$ It was reported that during the 2017 academic year the Institute have presently 163 memorizers in the ten, twenty and thirty $J_{u z u} a$ (Qur'anic chapters) categories. ${ }^{24}$ In addition, the Institute was established to produce Qur'anic prodigies who would be able to further their studies in academic institutions in Brunei or overseas, particularly Arabic countries. For example, there were thirty-six (36) students from the Institute who received special certificates from the Faculty of Usuluddin (UNISSA), during the 2016's Convocation.

\footnotetext{
${ }^{20}$ Brunei Darussalam Statistical Yearbook 2018. Brunei Darussalam: Department of Statistics, 201.

${ }^{21}$ Unstructured interview with Haji Abdul Rahman Bin Haji Nawi, former Director, Department of Curriculum Development, Ministry of Education, January 1, 2017, Brunei Darussalam; see also John R. Minnis (1999), "Is Reflective Practice Compatible with Malay-Islamic Values? Some Thoughts on Teacher Education in Brunei Darussalam.” Australian Journal of Education. Vol 4, No. 2, 172-185.

${ }^{22}$ Institute Tahfiz al-Qur'an Sultan Haji Hassanal Bolkiah (https://www.facebook.com/INSTITUTTAHFIZ-AL-QURAN-SULTAN-HAJI-HASSANAL-BOLKIAH-713085862144467/).

${ }^{23}$ Unstructured interview with Ustaz Pg. Haji Haslin Bin Haji Ali, Principal, Institute Tahfiz al-Qur'an Sultan Haji Hassanal Bolkiah, January 1, 2017, Brunei Darussalam.

${ }^{24}$ Radio Television Brunei (RTB), Report, "Al-Qur'an Memorizers.” Accessed January 2, 2017, from (http://www.rtbnews.rtb.gov.bn/index.php?option=com content\&view=article\&id=36834\%3Aal-quran-

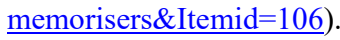


The Brunei College of Islamic Studies (Ma'had) in Tutong and the Seri Begawan Religious Teachers University College (KUPU-SB), formally known Maktab Perguruan Ugama, in BSB, both operate under the auspices of the Ministry of Religious Affairs. The Ma'had is an Islamic secondary school, which accommodates approximately 500 students, who study for a duration of five years (https://mahadislambrunei.wordpress.com/about). KUPU-SB, however, offers a three-year training program for more than 304 students, in an effort to qualify them to teach in religious schools around the country (http://www.kupusb.edu.bn). Both the Ma'had and KUPU SB teach traditional Islamic studies subjects such as Qur'an, Sunnah (Prophetic traditions), history, philosophy, Sufism (mysticism), Islamic law, particularly Shafi'e school of law. Abang Hadzmin Bin Abang Haji Taha asserted that,

KUPU-SB is a teacher's training college producing Islamic religious teachers where students are not only learning the Islamic studies courses but also how to teach Islamic courses. The Mahad, however, offers all standard subjects taught in public schools in addition to Islamic subjects, in a more thorough compared to public schools. $\left[{ }^{25}\right]$

At the tertiary level, the Sultan Omar Ali Saifuddien Centre for Islamic Studies (SOASCIS) was established in 2010, at the University of Brunei Darussalam, to provide postgraduate degrees i.e Master of Arts (M.A.) and Doctor of Philosophy (Ph.D.), by research, on Islamic civilization and contemporary issues (http://soascis.ubd.edu.bn/programs). In fact, SOASCIS was a substitute to the former Sultan Haji Omar Ali Saifuddin Institute of Islamic Studies (IPI) at the University, which was used to provide three different areas of specialization - Islamic Law (Shari'ah), Theology and Propagation (Usuluddin and Da'wah), and Arabic Language.

In 2007, and with a declaration from the Sultan, IPI was upgraded to the current Sultan Sharif Ali Islamic University (UNISSA), and becomes the first Islamic institution of higher learning in the country. Today, UNISSA have five (5) faculties and eight (8) centres. The University is considered an authentic Islamic institute of international standard, "offers a variety of programs across disciplines based on Al-Qur'an and al-Sunnah" (http://www.unissa.edu.bn/about-us/corporate-profile/rectors-message). Currently, UNISSA offers undergraduate and postgraduate degrees in major fields of Islamic studies such as Usuluddin (Islamic Studies), Shari'ah and Islamic law, business and management, Islamic banking and finance, Arabic language, Islamic civilization, development and management (http://www.unissa.edu.bn/programmes/programmes-offered).

\section{Conclusion}

This paper has attempted to undertake a critical appraisal of the traditional Islamic approach and contemporary western approach to educational institutions. It has discussed a number of the merits and deficiencies of the traditional approach in an attempt to propose some recommendations towards the development of a new system which will be more relevant to Islamic learning centres in the Southeast Asia.

In essence, any contemporary Islamic approach to education must view knowledge as a comprehensive whole and not of separating revealed knowledge from empirical knowledge. All conclusions should be validated by revealed knowledge, rather than superstition, black magic or other cultural mores and practices. Muslim scholars must be very careful for distinguishing between what is "truly" Islamic from what is of foreign origin, when conducting

\footnotetext{
${ }^{25}$ Unstructured interview with Dr. Abang Hadzmin Bin Abang Haji Taha, Deputy President, Seri Begawan Religious Teachers University College (KUPU-SB), December 31, 2016, Brunei Darussalam.
} 
research and publish academic works in the Islamic disciplines.

Greater technological literacy during the digital era, as well as improved literacy in both Arabic and English mediums, is also essential if Muslims want to facilitate their data collection, analysis and dissemination of research results. Muslim nations should co-operate together on areas of education and research of mutual benefit and concern, while Muslim academic institutions need to show greater leniency and tolerance to their scholars as well as nurture innovativeness and confidence in their educationists. At the grass roots level, madrassahs must widen their perspective on what is considered "Islamic knowledge", make their curriculums more relevant to the needs of their students and the larger society and encourage their students to undertake critical research in specialized disciplines from an Islamic perspective. If academic institutions and Muslims scholars are able to incorporate the above recommendations when teaching and/or conducting research on contemporary issues, then undoubtedly they will be one step further towards effectively resolving some of the many challenges faced by the ummah today and in the future.

Finally, this paper has demonstrated how Islamic values, traditions and ethics continue to be incorporated and manifested within Brunei's religious institutions, culture, society and politics, in the modern era. Although the government has played a significant role in creating and developing Islamic culture and religious values, educational and financial institutions, it also supporting Islamic programs in the media. It is hoped that this paper has contributed somewhat to providing a theoretical overview of the various religious and educational institutions in contemporary Brunei Darussalam.

Laying the foundational framework must not stop the developments however. Instead, there is a need for educational and definitely religious policy makers in Brunei Darussalam to further examine and study the initiatives undertaken by institutions in the Muslim world such as Indonesia, Turkey, Malaysia, Pakistan, Jordan, Egypt, and Morocco, which are at the forefront of "Islamic education" and its re-development. Brunei Darussalam can learn from their experiences, as well as avoid similar mistakes.

\section{References}

\section{A) Books, articles}

[1] Al-Attas, Syed Muhammad Naquib. Islam and Secularism. Kuala Lumpur, Malaysia: ABIM, 1978.

[2] Al-Faruqi, Ismail R. Al-Tawhid: Its Implications for Thought and Life. Virginia, USA: International Institute of Islamic Thought, 1992.

[3] Al-Najjar, Zaghlul R, "Islamizing the Teaching of Science: A Model in Challenge and Response," in Islam: Source and Purpose of Knowledge. Virginia, USA: International Institute of Islamic Thought, 1983.

[4] Bruinessen, Martin van. "The Origin and Development of Sufi Order (Tarekat) in South East Asia." Studia Islamika, (Indonesian Journal for Islamic Studies). 1994, Vol. 1, No. 1, 1-23.

[5] Department of Economic Planning and Development. Brunei Darussalam Millennium Development Goals and Beyond: Towards the Post-2015 Development Agenda. Brunei Darussalam: De partment of Economic Planning and Development, 2015.

[6] Department of Economic Planning and Development and Statistics. Brunei Darussalam Statistical Yearbook 2015. "Population." Accessed July 27, 2020, from http://www.depd.gov.bn/SitePages/Population.aspx.

[7] Formichi, Chiara, "Islamic Studies or Asian Studies? Islam in Southeast Asia." The Muslim World. 2016, Vol. 106, 696-718. 
[8] Hassan, M. Kamal, "Some Socio-Cultural Phenomena Which Hinder the Overall Progress of the Muslim Ummah: General Observations Related to the Malay Community in Malay-

sia Facing

Conference on

Subang

[9] Khalil, Imad al Din. "Islamization of Knowledge: A Methodology." Occasional Paper No. 2 .Virginia, USA: International Institute of Islamic Thought, 1991.

[10] Minnis, John R., "Is Reflective Practice Compatible with Malay-Islamic Values? Some Thoughts on Teacher Education in Brunei Darussalam." Australian Journal of Education.

1999, Vol 4, No. 2, 172-185.

[11] Schottmann, Sven Alexander, "Melayu Islam Beraja: The Politics of Legitimization in a Malay Islamic Monarchy." Review of Indonesian and Malaysian Affairs. 2006, Vol. 40, No.

$2,111-39$.

[12] The Constitution of Brunei Darussalam (1984). Revised Edition. Accessed July 26, 2020, from http://www.worldstatesmen.org/Brunei1984.PDF.

[13] Yousif, Ahmad, "Brunei." and "Islam in Brunei." Religions of the World, Second Edition: A Comprehensive Encyclopedia of Beliefs and Practices. Gordon J. Melton and Marin Baumann. (eds.). Santa Barbara, CA: ABC-Clio., 2010. e-Book. Accessed http://www.abcclio.com/product.aspx?id=52831.

July 27, 2020, from

[14] Yousif, Ahmad F, "Contemporary Religious Institutions in Brunei Darussalam (1967-2017)." In Kegemilangan Pemerintahan. Asbol bin Mail, Ampuan Tengah, Yusop Damit and

Rosli Ampal (eds.). Brunei Darussalam: Yayasan Sultan Haji Hassanal Bolkiah, 2018,185-

202.

[15] Yousif, Ahmad F, "Global Peace" in Higher Educational Institutions in Southeast Asia: A Study on Moderation in Brunei Darussalam." Paper presented at the Commonwealth Conference on "Sustainable Peace and Development in a Polarizing World: Perspectives and Con-

tributions

Brisbane, Australia. from Commonwealth Nations." April 9-11, 2018. Griffith University, https://www.griffith.edu.au/_data/assets/pdf_file/0030/408279/AhmadYousif.pdf

\section{B) Internet Sources}

[1] Brunei College of Islamic Studies (Ma'had), https://mahadislambrunei.wordpress.com/about.

[2] Department of Economic Planning and Development of Brunei Darussalam, "Population." http://www.depd.gov.bn/SitePages/Population.aspx.

[3] Institute Tahfiz al-Qur'an Sultan Haji Hassanal Bolkiah, https://www.facebook.com/INSTITUT-TAHFIZ-AL-QURAN-SULTANHAJI-HASSANAL-BOLKIAH-713085862144467/.

[4] Ministry of Religious Affairs, Brunei Darussalam, http://www.kheu.gov.bn/Theme/Home.aspx.

[5] Seri Begawan Religious Teachers University College (KUPU-SB), http://www.kupusb.edu.bn.

[6] Sultan Omar Ali Saifuddien Centre for Islamic Studies (SOASCIS), University of Brunei Darussalam, http://soascis.ubd.edu.bn/programs.

[7] Sultan Sharif Ali Islamic University (UNISSA), Brunei Darussalam, http://www.unissa.edu.bn.

\section{C) Unstructured Interviews}

[1] Unstructured interview with Dato Ismail Bin Haji Ibrahim, former Director, Institute of Islamic 
Understanding Malaysia (IKIM), Kuala Lumpur, Malaysia, October 15, 1995. Reconfirmed the interview during the Wasatiyyah's Conference in Makkah, Saudi Arabia May 29, 2019.

[2] Unstructured interview with Dr. Abang Hadzmin Bin Abang Haji Taha, Deputy President, Seri Begawan Religious Teachers University College (KUPU-SB), December 31, 2016, Brunei Darussalam.

[3] Unstructured interview with Haji Abdul Rahman Bin Haji Nawi, former Director, Department of Curriculum Development, Ministry of Education, January 1, 2017, Brunei Darussalam.

[4] Unstructured interview with Ustaz Pg. Haji Haslin Bin Haji Ali, Principal, Institute Tahfiz alQur'an Sultan Haji Hassanal Bolkiah, January 1, 2017, Brunei Darussalam. 